\title{
Study of the Stability during Aging of Mixed Cashew and Papaya Wine Produced with Palm Wine Sediment
}

\author{
Jean Ives Kablan Gnoumou1*, Doudjo Soro, Blanchard G. A. Adou Gnagne², Ernest K. Koffi² \\ ${ }^{1}$ Food, Chemical and Environmental Process Sciences, Félix Houphouët-Boigny National Polytechnic Institute, Yamoussoukro, \\ Ivory Coast \\ ${ }^{2}$ Laboratory of Biochemistry, Agriculture and Biological Ressource Valorization, Faculty of Biosciences, Félix Houphouët-Boigny \\ University, Abidjan, Ivory Coast \\ Email: *kablan.gnoumou18@inphb.ci
}

How to cite this paper: Gnoumou, J.I.K., Soro, D., Gnagne, B.G.A.A. and Koffi, E.K. (2022) Study of the Stability during Aging of Mixed Cashew and Papaya Wine Produced with Palm Wine Sediment. Food and Nutrition Sciences, 13, 181-194. https://doi.org/10.4236/fns.2022.132016

Received: January 19, 2022

Accepted: February 20, 2022

Published: February 23, 2022

Copyright $\odot 2022$ by author(s) and Scientific Research Publishing Inc. This work is licensed under the Creative Commons Attribution International License (CC BY 4.0).

http://creativecommons.org/licenses/by/4.0/ (c) (i) Open Access

\begin{abstract}
During the ageing of wine, many reactions occur generating enormous modifications. After pasteurization $\left(65^{\circ} \mathrm{C} / 5\right.$ minutes $)$ of the mixed cashew apple and papaya wine, physicochemical, microbiological and sensory analyses were performed during the two (2) months of aging. The results showed no significant variation between the young wine and the one aged for two (2) months for $\mathrm{pH}$, titratable acidity, alcoholic percentage and density. However, for ESR, vitamin $\mathrm{C}$, total anthocyanins and aroma a significant difference ( $\mathrm{p} \leq$ $0.05)$ was observed. This difference was observed during the first 45 days and then stabilized until the sixtieth day. Values ranged from $6.3^{\circ} \mathrm{B}$ to $5.5^{\circ} \mathrm{B}$; from $84.65 \pm 0.6$ to $77.9 \pm 0.2 \mathrm{mg} / 100 \mathrm{~mL}$; from $165.5 \pm 0.8$ to $50.25 \pm 0.3 \mathrm{mg} / 100 \mathrm{~mL}$ for $\mathrm{RDE}$, vitamin $\mathrm{C}$ and total anthocyanins respectively. For aroma, there was more development between the young wine and the one aged for two months. Concerning the sanitary quality, there is a progressive decrease of the different germs during the aging period. Except for yeasts, which are undetectable, the load of aerobic mesophilic germs and lactic acid bacteria varies respectively from $3.5 \times 10^{5}$ to $1.4 \times 10^{5} \mathrm{CFU} / \mathrm{mL}$ and from $1.5 \times 10^{5}$ to $1 \times 10^{5} \mathrm{CFU} / \mathrm{mL}$.
\end{abstract}

\section{Keywords}

Stability, Aging, Wine, Sediment, Papaya, Cashew Apple

\section{Introduction}

In recent decades, winemakers have been particularly focused on enriching wines, through the search for better quality of the raw material, its extraction, and its aging [1]. However, the elements constituting this richness are not as sta- 
ble and easy to bottle regardless of the wines (white or red). According to [1], the objectives of clarity and stability (including coloring matters and microbiology), are rarely achieved naturally even if the extension of the maturation time can improve some elements, it does not solve all the problems (turbidity, filterability, microbiology). Therefore, the wines must be stabilized to guarantee their quality. A wine is a complex mixture of organic and inorganic compounds [2], including esters, high alcohols, fixed acidity (malic, tartaric and citric acids), sugars, aldehydes, tannins. According to [3], thanks to this alcohol and acid content, pasteurization is sufficient to guarantee the stability of wines.

Nowadays, the large amount of production in the agricultural sector needs to be highly processed in order to reduce post-harvest losses or to valorize some raw materials. Thus, this study will show other uses of fruits such as cashew apple (Anarcadium occidental L.) and papaya (Carica papaya L.) in order to compensate for the effort of farmers.

The cashew apple represents 9 to 10 times the weight of the nut, so very large quantities of cashew apple are available. It is very rich in nutrients. It is $85 \%$ sweet $\left(7^{\circ} \mathrm{B}-13^{\circ} \mathrm{B}\right)$, acidic juice, rich in vitamin $\mathrm{C}$ [4] [5] and polyphenols [6].

The papaya, belonging to the caricaceous family, is an orange berry with a delicious taste from a tropical tree plant native to Central and South America [7]. It is rich in $\mathrm{RDE}\left({ }^{\circ} \mathrm{Brix}\right) 10-15 \mathrm{~g}$ per $100 \mathrm{~g}$ of fresh material, vitamin $\mathrm{C}, \mathrm{A}$, beta-carotene, fiber and mineral elements [7] [8]. These raw materials are readily available and rich in reducing, fermentable sugars such as glucose and fructose.

The general objective is to carry out a study of stability during the maturation of the mixed wine of cashew apple and papaya and specifically to evaluate the physicochemical, microbiological and sensory parameters of the various wines elaborated during a period of aging of two (2) months.

\section{Material and Methods}

\subsection{Materiel}

The plant material consists of cashew apple (Anarcadium occidental L.), papaya (Carica papaya L.) and palm wine (Elaeis guineensis). These raw materials come from Yamoussoukro, the political capital of Côte d'Ivoire, in the Aries region, located between the forest and savannah zones. The cashew and papaya apples were harvested in the fields and transported to the factory of the Félix Houphouët-Boigny National Polytechnic Institute of Yamoussoukro (Ivory Coast) for the various extractions. As for the palm wine, it was extracted from the farmers of "Logbakro", a village located near Yamoussoukro and sent to the laboratory for the use of the sediment.

\subsection{Methods}

\subsubsection{Extraction of the Different Juices}

The fruits harvested consist of cashew apples and papaya. The apples were care- 
fully separated from the nuts using a wire tied at both ends with small pieces of wood to avoid damaging them. The obtained cashew apples and ripe papaya were soaked in water bleached with one hundred ppm (100 ppm) active chlorine for 15 - 20 minutes and then rinsed with potable water. After trimming the papaya, the different raw materials were pressed using a hydraulic press. The juice obtained was then filtered through a one-millimeter diameter mesh screen and then packaged in five (5) liters drums and stored at $-4^{\circ} \mathrm{C}$ before formulation of the must.

\subsubsection{Production of Ferment from Palm Wine Sediment}

Palm wine is obtained from the exploitation of oil palm (Elaeis guineensis). The samples were taken from palms that had been harvested for at least 14 days. These different palm wine samples were collected in 1 to $1.5 \mathrm{~L}$ plastic containers disinfected with $8^{\circ} \mathrm{chl}$ chlorine at one hundred ppm (100) ppm and then sent to the laboratory. Then, they were centrifuged at $3000 \mathrm{rpm}$ for one minute and the collected pellet was fermented for 50 hours at $30^{\circ} \mathrm{C} \pm 2^{\circ} \mathrm{C}$. $7.4 \mathrm{~mL}$ of this fermented pellet was used as inoculum.

\subsubsection{Production of Mixed Wine or Must Fermentation Procedure}

After extraction, the cashew apple and papaya juices were weighed and proportions consisting of 50\% cashew apple juice and 50\% papaya juice (50:50 volume per volume) were used. A total mixture of 20 liters of juice was poured into a 25 liters canister previously disinfected for 15 - 20 minutes with one hundred ppm (100 ppm) active chlorine. This canister was used as a fermenter, hermetically sealed and piped to another canister containing water in order to release the carbon dioxide developed during fermentation. To this must, cane sugar was added for chaptalization (correction of the Brix degree to $20^{\circ} \mathrm{B}$ ) and palm wine sediment $(7.4 \mathrm{~mL}$ of sediment for one liter of must). Fermentation was carried out for a period of 14 days at $30^{\circ} \mathrm{C} \pm 2^{\circ} \mathrm{C}$. When the Brix degree remained stable over two (2) to three (3) days (cessation of fermentation), the resulting wine was then stabilized by heating at $65^{\circ} \mathrm{C}$ for 5 minutes. During wine production, fermentation kinetics were monitored, $\mathrm{pH}$, specific gravity, refractometric dry extract $(\mathrm{RDE})$, total sugars, reducing sugars, titratable acidity, volatile acidity and alcoholic percentage were controlled every 24 hours. A wine control was produced under the same conditions using industrial yeast as ferment. The production diagram of the mixed wine based on cashew apple and papaya juice is shown in Figure 1.

\subsubsection{Physico-Chemical and Biochemical Analysis}

\section{1) $\mathrm{pH}$}

The $\mathrm{pH}$ was determined according to the AOAC method [9]. $50 \mathrm{~mL}$ of the samples were used for $\mathrm{pH}$ determination after calibration of the $\mathrm{pH}$-meter (HI 5221-02, HANNA Instruments, Woonsocket, RI, USA).

\section{2) Titratable acidity}

The determination of titratable acidity was done by acid-base assay according 


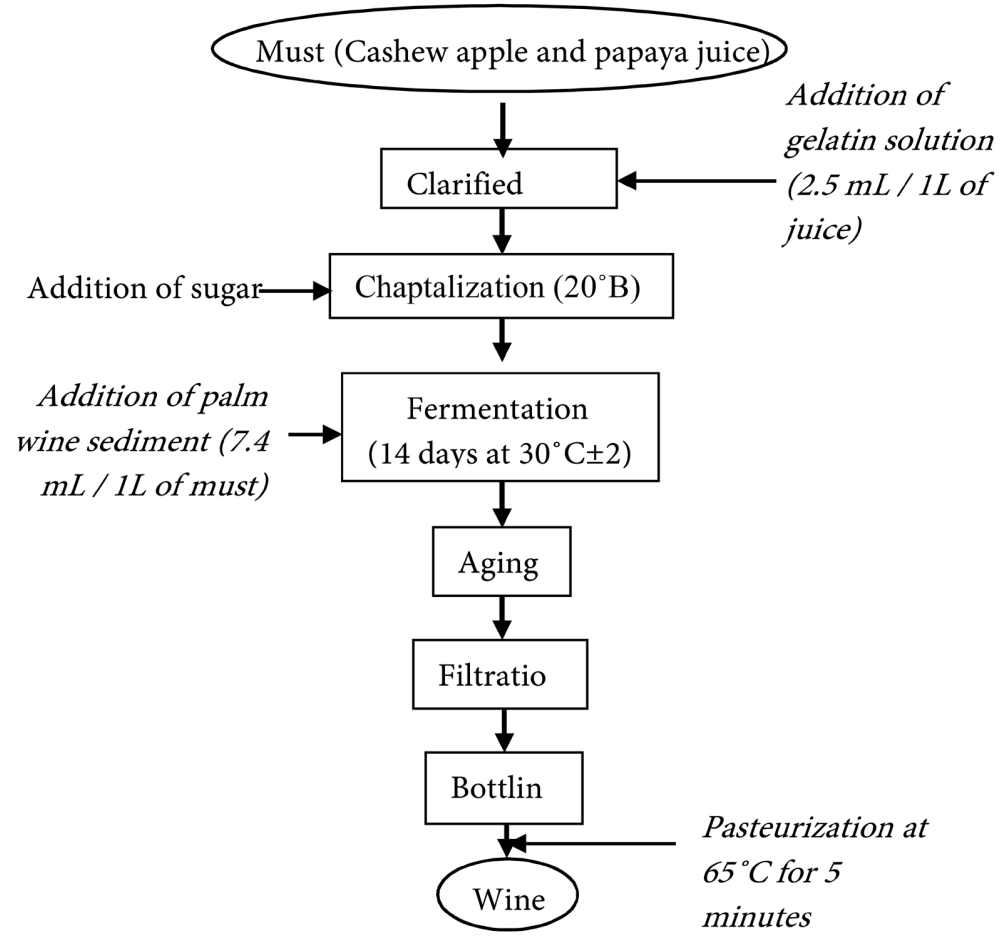

Figure 1. Production diagram of mixed wine made from cashew apple and papaya juice.

to the AOAC method [9]. In the presence of two drops of phenolphthalein (Showa chemicals Industry, Tokyo, Japan), $10 \mathrm{~mL}$ of sample contained in an Erlenmeyer flask was assayed with a sodium hydroxide solution $0.1 \mathrm{~N}$ (Panreac, Espagne). The pink turn of the solution was used to determine the volume of soda required to neutralize the titratable acidity contained in the samples.

$$
\mathrm{TA}\left(\frac{\mathrm{g}}{\mathrm{L}}\right)=\frac{\mathrm{NNaOH} \times \mathrm{VNaOH} \times 0.064}{\mathrm{Vsamp}} \times 100
$$

$\mathrm{VNaOH}=$ volume of sodium hydroxide required for the determination $(\mathrm{mL})$;

$\mathrm{NNaOH}=$ normality of the sodium hydroxide in meq/L;

Vsamp = volume of the test sample in $\mathrm{mL}$;

$0.064=$ milliequivalent gram of citric acid.

\section{3) Refractometric dry extract (RDE)}

Refractometric dry extract was determined by the AOAC method [9]. A drop of the sample was placed on the glass of the pocket refractometer (Model ATAGO IP65, POCKET REFRACTOMETER, Tokyo, Japon) to evaluate the number of suspended solids. The reading of the refractometric dry extract value was done in the light, at the eyepiece of the apparatus.

\section{4) Specific gravity}

The density is determined by taking the ratio of the density of a sample to the density of water according to the usual method [10].

\section{5) Percentage of alcohol}

The alcoholic degree was determined by the distillation method [9]. The principle is the separation of ethanol contained in the sample by distillation, then 
oxidation in sulfuric medium by potassium dichromate (Panreac, Espagne).

\section{6) Vitamin $C$ content}

The ascorbic acid content is measured by the 2,6-dichlorophenolindophenol (2,6-DCPIP) (Sigma-Aldrich, St. Louis, MO, USA) titration method. The method consists of a reduction of 2,6-DCPIP and an oxidation of ascorbic acid to dehydroascorbic acid. It therefore allows a determination of the vitamin $\mathrm{C}$ content in its reduced form (ascorbic acid). Once the oxidation of ascorbic acid is complete, 2,6-DCPIP serves as a color indicator and its presence in solution gives a characteristic pink color [9].

$$
\text { Vit } C=\frac{(\mathrm{Ve}-\mathrm{Vo}) \times 20}{(\mathrm{Vs}-\mathrm{Vo}) \times 10} \times 100
$$

Vit C: Vitamin C concentration of the sample $(\mathrm{mg} / 100 \mathrm{~mL})$;

Ve: volume of 2 - 6 dichlorophenolindophenol poured to neutralize the "sample" metaphosphoric acid/acetic acid solution $(\mathrm{mL})$;

Vs: volume of 2 - 6 dichlorophenolindophenol poured to neutralize the vitamin C standard solution ( $\mathrm{mL}$ );

Vo: volume of 2 - 6 dichlorophenolindophenol added to neutralize the metaphosphoric acid/acetic acid solution $(\mathrm{mL})$.

\section{7) Total anthocyanins content}

Anthocyanin content was determined according to the method described by [11]. $1 \mathrm{~mL}$ of each sample was diluted in $1.5 \mathrm{~mL}$ of buffer $\mathrm{pH} 1.0$ and $1.5 \mathrm{~mL}$ of buffer $\mathrm{pH} 4.5$, respectively. The absorbance (A) of these two solutions was read by a UV-visible spectrometer (JASCO V-530) at 520 nanometers and 700 nanometers, respectively.

\subsubsection{Microbiological Analyses}

The enumeration of total germs concerns mainly aerobic mesophilic bacteria after $72 \mathrm{~h}$ of incubation at $30^{\circ} \mathrm{C}$ on PCA agar. The method used is the one described by the standard NF V 08-051 [12].

The enumeration of yeasts was performed according to the NF-V08-022 standard. The isolation medium used was Sabouraud agar with chloramphenicol $(0.05 \mathrm{~g} / \mathrm{L})$. By spreading, $0.1 \mathrm{~mL}$ of each decimal dilution was plated on the agar previously poured and solidified in Petri dishes. Incubation was performed at $30^{\circ} \mathrm{C}$ for 48 hours in an oven.

The medium used for the enumeration of lactic acid bacteria is Man Rosa Sharp (MRS) agar [13]. On the solidified medium in petri dishes, $0.1 \mathrm{~mL}$ of the stock suspension or of the retained dilutions is deposited on the surface of the previously poured agar and spread with a spreader rake. Petri dishes are incubated anaerobically for 48 to 72 hours at $30^{\circ} \mathrm{C}$. Colony count is done by counting colonies between 30 and 300 .

\subsubsection{Hedonic Test}

The panel was constituted with 50 untrained people composed of $\mathrm{PhD}$ students, students and trainees of the Félix Houphouët-Boigny National Polytechnic In- 
stitute of Yamoussoukro (Ivory Coast), recruited on the basis of their availability. Coded wine samples (with three digits) were presented monadically (one after the other) to each panelist in a randomized order. Pleasure on the aroma perceived by each panelist was scored on a nine-point hedonic scale.

\subsubsection{Statistical Analysis}

The results obtained during the study were statistically analyzed using STATISTICA software version 7.1. A one-way analysis of variance (ANOVA) was performed. Statistically significant differences were highlighted by the Newman-Keuls test at the $5 \%$ threshold.

\section{Results and Discussion}

\subsection{Physico-Chemical and Biochemical Analyses}

The mixed cashew apple and papaya wines produced with palm wine sediment treated by pasteurization $\left(65^{\circ} \mathrm{C} / 5\right.$ minutes) were analyzed from a physicochemical, microbiological and sensory point of view following a two (2) month aging phase. The palm wine sediment used as ferment in this study contains a large population of fermentative microorganisms dominated by yeast. The work of [14] [15] showed that among the microorganisms contained in the natural palm wine microflora, Saccharomyces cerevisiae is the species responsible for alcoholic fermentation and aroma. The results of the stability of the wines showed that the samples would be stored for a long period of time without deteriorating. Thus, no significant variation was observed for quality parameters such as $\mathrm{pH}$, titratable acidity, alcoholic percentage and specific gravity (Figures 2-5). On the

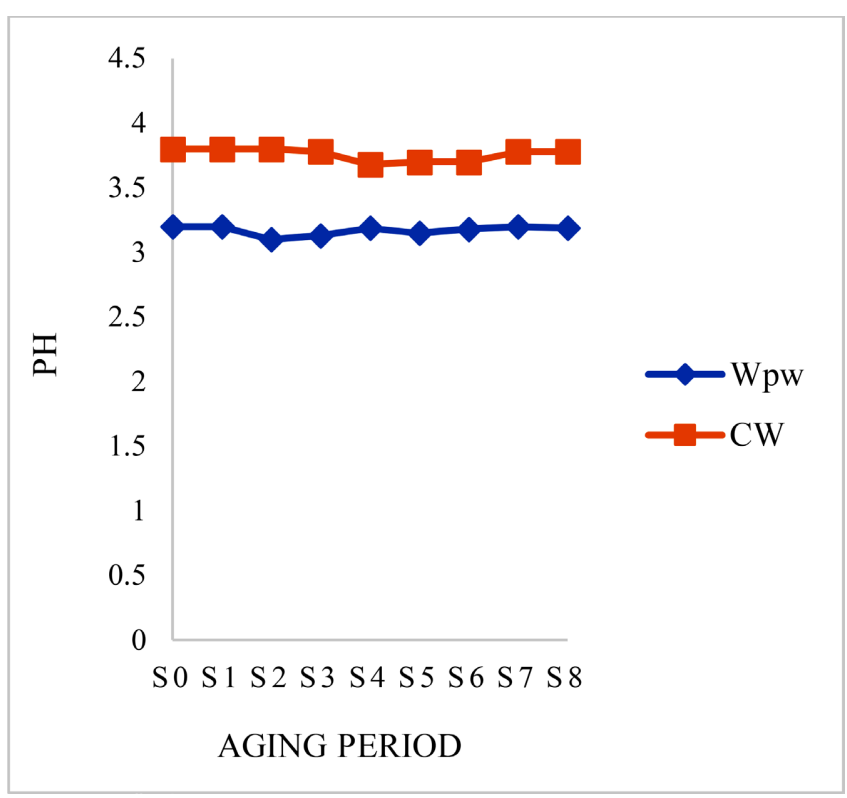

S0: young wine; S1: $1^{\text {st }}$ week of aging; S2: $2^{\text {nd }}$ week; S3: $3^{\text {rd }}$ week; S4: $4^{\text {th }}$ week; S5: $5^{\text {th }}$ week; S6: $6^{\text {th }}$ week; S7: $7^{\text {th }}$ week and S8: $8^{\text {th }}$ week of aging. Wpw: Wine obtained from palm wine sediment; CW: Wine obtained from industrial yeast or control wine.

Figure 2. Evolution of $\mathrm{pH}$ during the aging of mixed wine. 


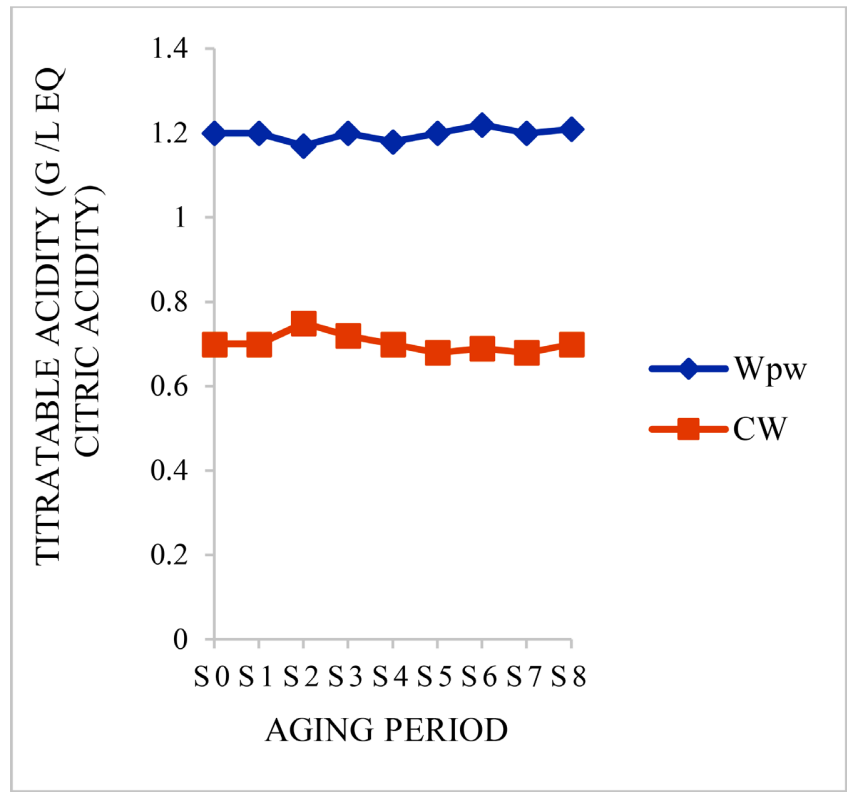

S0: young wine; S1: $1^{\text {st }}$ week of aging; S2: $2^{\text {nd }}$ week; S3: $3^{\text {rd }}$ week; S4: $4^{\text {th }}$ week; S5: $5^{\text {th }}$ week; S6: $6^{\text {th }}$ week; S7: $7^{\text {th }}$ week and S8: $8^{\text {th }}$ week of aging. Wpw: Wine obtained from palm wine sediment; CW: Wine obtained from industrial yeast or control wine.

Figure 3. Evolution of titratable acidity during the aging of mixed wine.

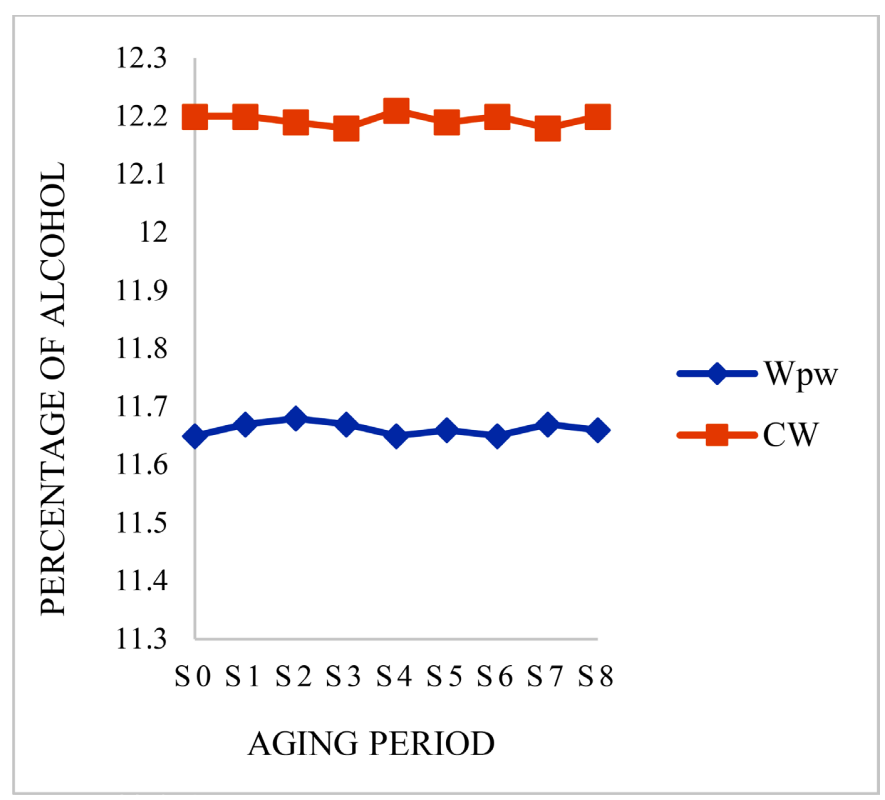

S0: young wine; S1: $1^{\text {st }}$ week of aging; S2: $2^{\text {nd }}$ week; S3: $3^{\text {rd }}$ week; S4: $4^{\text {th }}$ week; S5: $5^{\text {th }}$ week; S6: $6^{\text {th }}$ week; S7: $7^{\text {th }}$ week and S8: $8^{\text {th }}$ week of aging. Wpw: Wine obtained from palm wine sediment; CW: Wine obtained from industrial yeast or control wine.

Figure 4. Evolution of the alcoholic percentage during the aging of the mixed wine.

other hand, there was a significant difference $(\mathrm{p} \leq 0.05)$ between the values of RDE, vitamin $C$ and total anthocyanins (Figures 6-8) and aroma (Table 1). This difference was observed during the first 45 days and then stabilized until the sixtieth days. Values ranged from $6.3^{\circ} \mathrm{B}$ to $5.5^{\circ} \mathrm{B}$; from $84.65 \pm 0.6$ to $77.9 \pm 0.2$ 


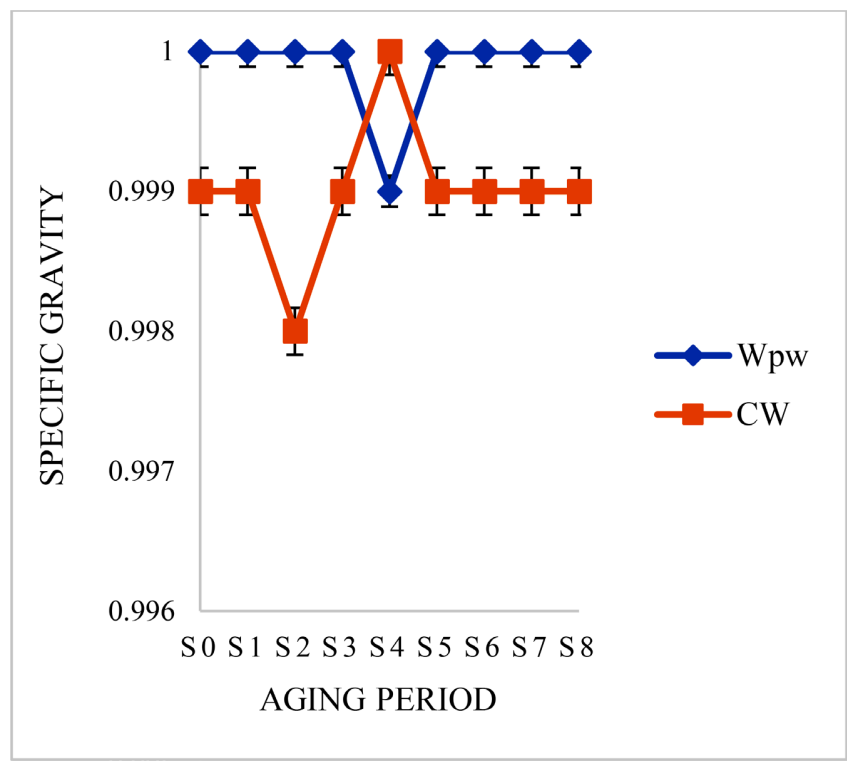

S0: young wine; S1: $1^{\text {st }}$ week of aging; S2: $2^{\text {nd }}$ week; S3: $3^{\text {rd }}$ week; S4: $4^{\text {th }}$ week; S5: $5^{\text {th }}$ week; S6: $6^{\text {th }}$ week; S7: $7^{\text {th }}$ week and S8: $8^{\text {th }}$ week of aging. Wpw: Wine obtained from palm wine sediment; CW: Wine obtained from industrial yeast or control wine.

Figure 5. Evolution of the specific gravity during the aging of mixed wine

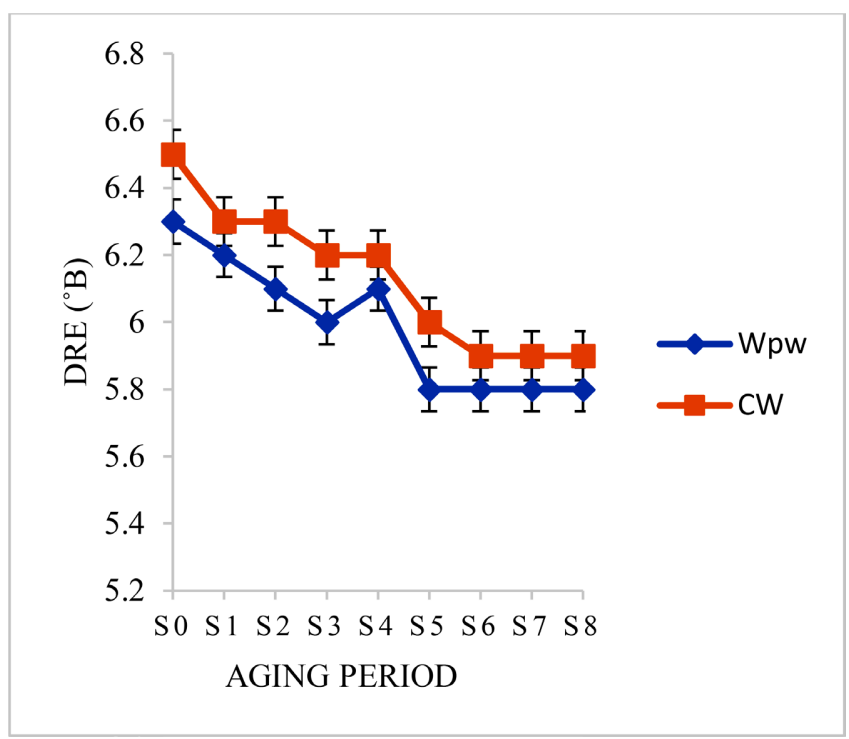

S0: young wine; S1: $1^{\text {st }}$ week of aging; S2: $2^{\text {nd }}$ week; S3: $3^{\text {rd }}$ week; S4: $4^{\text {th }}$ week; S5: $5^{\text {th }}$ week; S6: $6^{\text {th }}$ week; S7: $7^{\text {th }}$ week and S8: $8^{\text {th }}$ week of aging. Wpw: Wine obtained from palm wine sediment; CW: Wine obtained from industrial yeast or control wine.

Figure 6. Evolution of the residual dry extract during the aging of the mixed wine

$\mathrm{mg} / 100 \mathrm{~mL}$; from $165.5 \pm 0.8$ to $50.25 \pm 0.3 \mathrm{mg} / 100 \mathrm{~mL}$ for RDE, vitamin $\mathrm{C}$ and total anthocyanins respectively. For aroma, there was a greater development between the young wine and the one aged for two months. Indeed, these variations are correlated by the accentuation of the color of the different wine samples. This variation would be due to the condensation reactions of polyphenols (anthocyanins and flavanols). This change in color is correlated with the decrease in total 


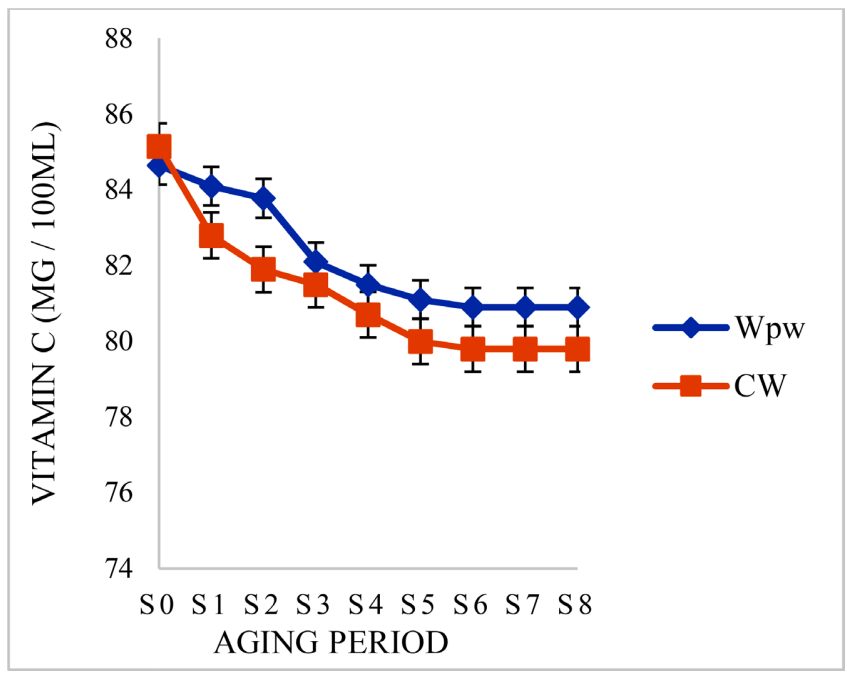

S0: young wine; S1: $1^{\text {st }}$ week of aging; S2: $2^{\text {nd }}$ week; S3: $3^{\text {rd }}$ week; S4: $4^{\text {th }}$ week; S5: $5^{\text {th }}$ week; S6: $6^{\text {th }}$ week; S7: $7^{\text {th }}$ week and S8: $8^{\text {th }}$ week of aging. Wpw: Wine obtained from palm wine sediment; CW: Wine obtained from industrial yeast or control wine.

Figure 7. Evolution of vitamin $\mathrm{C}$ during the aging of mixed wine.

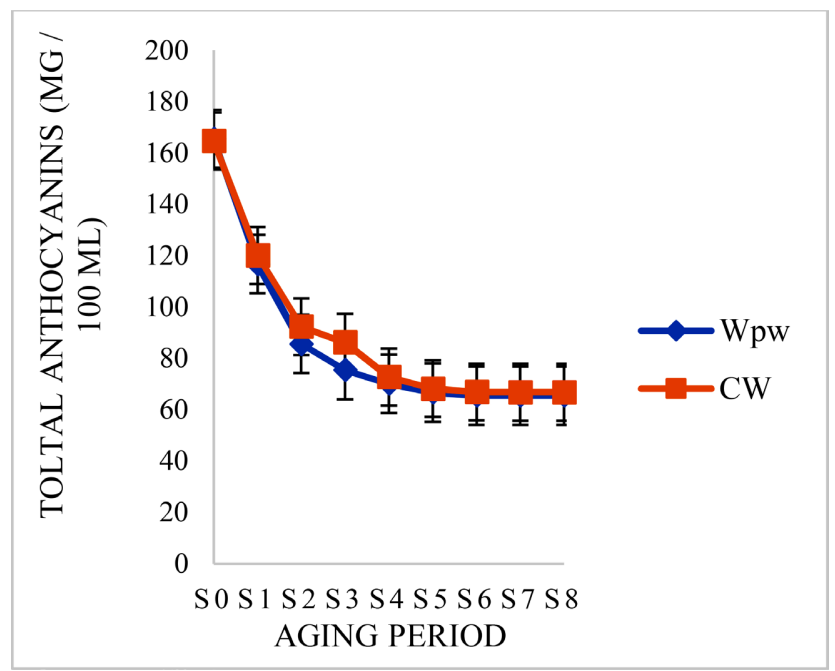

S0: young wine; S1: $1^{\text {st }}$ week of aging; S2: $2^{\text {nd }}$ week; S3: $3^{\text {rd }}$ week; S4: $4^{\text {th }}$ week; S5: $5^{\text {th }}$ week; S6: $6^{\text {th }}$ week; S7: $7^{\text {th }}$ week and S8: $8^{\text {th }}$ week of aging. Wpw: Wine obtained from palm wine sediment; CW: Wine obtained from industrial yeast or control wine.

Figure 8. Evolution of total anthocyanins during the aging of mixed wine.

Table 1. Evaluation of the aroma between the young wine and the wine aged for two months.

\begin{tabular}{ccc}
\hline Sample & S0 & S8 \\
\hline Wwp & $6.1 \pm 1.1^{\mathrm{a}}$ & $8.75 \pm 1.0^{\mathrm{b}}$ \\
CW & $5.6 \pm 1.3^{\mathrm{a}}$ & $8.5 \pm 1.2^{\mathrm{b}}$ \\
\hline
\end{tabular}

Values are means \pm standard deviation of 50 panelists. Values with the same superscript in a column are not significantly different $(\mathrm{p}<0.05)$. S0: young wine; S8: $8^{\text {th }}$ week of aging. Wpw: Wine obtained from palm wine sediment; CW: Wine obtained from industrial yeast or control wine. 
anthocyanins. This observation is similar to the work of [16] performed on an aging time of 30 days. Similarly, a rapid decrease in anthocyanins of up to $98 \%$ was observed over a 12-week aging period in blueberry wine [17]. Indeed, according to [16] [18] and [19], condensation reactions between anthocyanins and other phenolic compounds (copigmentation) are the most effective reactions causing more enhanced color changes in wine. For [20], the newly formed pigments are more stable than native anthocyanins thus positively affecting color stability and protecting the wine from further oxidation. This is justified by the color stability of the different wine samples obtained after an aging time of 45 days. According to [21], wine color is the first latent variable, which is associated with the variation of anthocyanins, polymeric pigments, total phenols, and total flavonoids. Indeed, the richness of these wines in anthocyanins and vitamin $\mathrm{C}$ is important because these parameters have many biological properties among others a strong antioxidant activity. According to [22], this activity not only protects macromolecules from degradation but also organs such as the heart and arteries. Also, these color variations during aging of different wines could be attributed to non-enzymatic browning or even the Maillard reaction. Indeed, in addition to chemical browning reactions involving wine phenols, the main browning reactions occurring during wine preservation or aging are the Maillard reaction [23]. The Maillard reaction involves the condensation of the carbonyl group of reducing sugars with the amino groups of amino acids and/or proteins occurring in foods during processing and cooking or even during storage giving rise to different compounds that include reductones, furfurals and a variety of other cyclic substances [24]. These reductones formed by the Maillard reaction could also be derived from the aerobic and anaerobic degradation of vitamin $\mathrm{C}$ since it has an obvious similarity with structural hexoses [25]. Therefore, it is conceivable that its carbonyl group could be involved in the condensation reaction.

\subsection{Microbiological Analyses}

The results obtained from the evaluation of the hygienic and sanitary quality of mixed cashew apple and papaya wines during the two (2) months of maturation are presented in Tables 2-4. There is a progressive decrease of the different aerobic mesophilic germs, yeasts and lactic bacteria during the aging period. Except for yeasts, which are undetectable, the load of aerobic mesophilic germs and lactic acid bacteria varies from $3.5 \times 10^{5}$ to $1.4 \times 10^{5} \mathrm{cfu} / \mathrm{mL}$ and from $1.5 \times 10^{5}$ to $1 \times 10^{5} \mathrm{cfu} / \mathrm{mL}$, respectively. Indeed, the decrease in germs in the wine samples during the two months of aging could be specifically due to the composition of the reaction medium consisting of alcohol, organic acids and other metabolites [2] [26]. Such an environment would contribute to the resistance of the wine against proliferating microorganisms [27]. The absence of yeasts and the decrease of bacteria showed that the different wines obtained achieved the appropriate characteristics of a good wine. This could be related to the acidic environment (acidic 
Table 2. Evolution of mesophilic aerobic germs $(\mathrm{CFU} / \mathrm{mL})$ during aging.

\begin{tabular}{cccccccccc}
\hline \multicolumn{10}{c}{ Aging period } \\
\hline Samples & S0 & S1 & S2 & S3 & S4 & S5 & S6 & S7 & S8 \\
\hline Wwp & $3.5 \times 10^{5}$ & $3 \times 10^{5}$ & $3.1 \times 10^{5}$ & $2.5 \times 10^{5}$ & $2.2 \times 10^{5}$ & $2 \times 10^{5}$ & $2.3 \times 10^{5}$ & $1.9 \times 10^{5}$ & $1.4 \times 10^{5}$ \\
CW & $2.8 \times 10^{5}$ & $3.1 \times 10^{5}$ & $2.8 \times 10^{5}$ & $2.5 \times 10^{5}$ & $2.5 \times 10^{5}$ & $2.1 \times 10^{5}$ & $1.5 \times 10^{5}$ & $1.6 \times 10^{5}$ & $1.5 \times 10^{5}$ \\
\hline
\end{tabular}

Values are in mean of duplicate determination. S0: young wine; S1: $1^{\text {st }}$ week of aging; S2: $2^{\text {nd }}$ week; S3: $3^{\text {rd }}$ week; S4: $4^{\text {th }}$ week; S5: $5^{\text {th }}$ week; S6: $6^{\text {th }}$ week; S7: $7^{\text {th }}$ week and S8: $8^{\text {th }}$ week of aging. Wpw: Wine obtained from palm wine sediment; CW: Wine obtained from industrial yeast or control wine.

Table 3. Evolution of yeast $(\mathrm{CFU} / \mathrm{mL})$ during aging.

\begin{tabular}{cccccccccc}
\hline \multicolumn{10}{c}{ Aging period } \\
\hline Samples & S0 & S1 & S2 & S3 & S4 & S5 & S6 & S7 & S8 \\
\hline Wwp & ND & ND & ND & $2 \times 10$ & ND & $1 \times 10$ & ND & ND & ND \\
CW & ND & $1 \times 10$ & ND & ND & $1 \times 10$ & ND & ND & ND & ND \\
\hline
\end{tabular}

Values are in mean of duplicate determination. S0: young wine; S1: $1^{\text {st }}$ week of aging; S2: $2^{\text {nd }}$ week; S3: $3^{\text {rd }}$ week; S4: $4^{\text {th }}$ week; S5: $5^{\text {th }}$ week; S6: $6^{\text {th }}$ week; S7: $7^{\text {th }}$ week and S8: $8^{\text {th }}$ week of aging. Wpw: Wine obtained from palm wine sediment; CW: Wine obtained from industrial yeast or control wine.

Table 4. Evolution of lactic acid bacteria $(\mathrm{CFU} / \mathrm{mL})$ during aging.

\begin{tabular}{cccccccccc}
\hline \multicolumn{10}{c}{ Aging period } \\
\hline Samples & S0 & S1 & S2 & S3 & S4 & S5 & S6 & S7 & S8 \\
\hline Wwp & $1.4 \times 10^{5}$ & $1.5 \times 10^{5}$ & $1.4 \times 10^{5}$ & $1.3 \times 10^{5}$ & $1.2 \times 10^{5}$ & $1.4 \times 10^{5}$ & $1.5 \times 10^{5}$ & $1.2 \times 10^{5}$ & $1 \times 10^{5}$ \\
CW & $1.5 \times 10^{5}$ & $1.2 \times 10^{5}$ & $1.4 \times 10^{5}$ & $1.4 \times 10^{5}$ & $1.5 \times 10^{5}$ & $1.3 \times 10^{5}$ & $1.4 \times 10^{5}$ & $1.2 \times 10^{5}$ & $1.2 \times 10^{5}$ \\
\hline
\end{tabular}

Values are in mean of duplicate determination. S0: young wine; S1: $1^{\text {st }}$ week of aging; S2: $2^{\text {nd }}$ week; S3: $3^{\text {rd }}$ week; S4: $4^{\text {th }}$ week; S5: $5^{\text {th }}$ week; S6: $6^{\text {th }}$ week; S7: $7^{\text {th }}$ week and S8: $8^{\text {th }}$ week of aging. Wpw: Wine obtained from palm wine sediment; CW: Wine obtained from industrial yeast or control wine.

$\mathrm{pH}$ and high total acidity) of the wine [28]. It has been reported that the antimicrobial activity of organic acids is due to their dissociation ability [2]. Indeed, the biological membranes of most microorganisms are permeable to the undissociated form of these molecules which, when it enters the cytoplasm of the cell, dissociates and participates in strongly reducing the intracellular $\mathrm{pH}$ within the microbial cell. These changes can greatly inhibit energy production which can induce cell death [29].

\section{Conclusion}

This study showed that the different wines elaborated and aged for eight weeks (60 days) are nutritious and can be used as a thirst-quenching drink. Indeed, after a pasteurization of $65^{\circ} \mathrm{C}$ for 5 minutes $\left(65^{\circ} \mathrm{C} / 5\right.$ minutes), the different clarified and aged wines gave very good qualitative characteristics. These results also show the efficiency of the treatment during the vinification. These wines can be 
kept for a long period without being altered. However, in order to guarantee this stability for a very long period of time while avoiding variations during maturation or aging, a low dose sulfite treatment could be recommended. Also, palm wine sediment can be an ideal substitute for industrial yeast as inoculum for alcoholic fermentation.

\section{Importance of Current Research}

This study is part of the research approach of valorization of agricultural productions by using the palm wine sediment to produce a mixed wine from cashew apple and papaya. Thus, it will allow reducing not only post-harvest losses, but also creating additional income for the actors of the different sectors.

\section{Acknowledgements}

We thank the Director and the technicians of the Department of Chemical and Food Engineering, Félix Houphouët-Boigny National Polytechnic Institute of Yamoussoukro (Ivory Coast) for providing us with all the reagents to perform the analyses.

\section{Conflicts of Interest}

The authors declare no conflicts of interest regarding the publication of this paper.

\section{References}

[1] Romat, H., Crachereau, J.-C. and Furet, M.-I. (2018) Clarification et stabilité des vins en vue de l'embouteillage: Problématique et perspectives. MatéVi Banque de données des matériels viti-vinicoles, Institut Français de la vigne et du vin (IFV), lettre actualités, No. 6, 1-8.

[2] Ajogun, C.O., Achinewhu, S.C., Kiin-Kabari, D.B. and Akusu, O.M. (2020) Physicochemical, Sensory and Microbiological Quality of Table Wine Produced from Coconut Water, Honey and Zobo. European Journal of Agriculture and Food Sciences, 2, 1-8. https://doi.org/10.24018/ejfood.2020.2.5.102

[3] Ribéreau-Gayon, P., Glories, Y., Maujean, A. and Dubourdieu, D. (2012) Traité d'œnologie Tome 2 Chimie du vin. Stabilisation et traitements, Dunod.

[4] Dedehou, E.S.C.A., Dossou, J., Anihouvi, V. and Soumanou, M.M. (2016) A Review of Cashew (Anacardium occidentale L.) Apple: Effects of Processing Techniques, Properties and Quality of Juice. African Journal of Biotechnology, 15, 2637-2648.

[5] Ouattara, G.S., Soro, D., Chatigre, K.O. and Koffi, K.E. (2016) Caractérisation physico-chimique et sensorielle de diverses formulations de jus à base de pomme de cajou et d'ananas. International Journal of Biological and Chemical Sciences, 10, 2447-2460. https://doi.org/10.4314/ijbcs.v10i6.4

[6] Michodjehoun-Mestres, L, Souquet, J.M., Fulcrand, H., Bouchut, C., Reynes, M. and Brillouet, J.-M. (2009) Monomeric Phenols of Cashew Apple (Anacardium occidentale L.). Food Chemistry, 112, 851-857. https://doi.org/10.1016/j.foodchem.2008.06.056

[7] Koffi, E.L., Koffi, D.M., Konan, K.H. and Kouadio, N.E.J.P. (2020) Effect of the Ri- 
pening Stages on Some Biochemical and Nutritional Properties in Carica papaya L. (cv. Solo 8) Pulp, Skin, and Seeds. European Journal of Nutrition \& Food Safety, 12, 1-9. https://doi.org/10.9734/ejnfs/2020/v12i1030297

[8] Fabert, C.M. (2011) Le papayer, Carica papaya L., de la médecine traditionnelle à la médecine actuelle: Études botaniques et pharmacognosique. Thèse pour le Diplôme d'Etat de Docteur en Pharmacie, Université de Limoges, Limoges, 129 p.

[9] Official Analytical Chemical International (2010) Official Method of Analysis of Association of Official Analytical Chemical International. 18th Edition, AOAC International, Gaithersburg.

[10] Aka, S., N’Dédé, T.D., Kouadio, F.N., Kouadio, C.Y. and Koffi, M.D. (2008) Variabilité des propriétés physico-chimiques et dénombrement de la flore fermentaire du tchapalo, une bière traditionnelle de sorgho en Côte d'Ivoire. African Science, 4, 274-286. https://doi.org/10.4314/afsci.v4i2.61688

[11] Lee, J., Durst, R.W., Wrolstad, R.E., Eisele, T., Giusti, M.M. and Hach, J. (2005) Determination of Total Monomeric Anthocyanin Pigment Content of Fruit Juices, Beverages, Natural Colorants, and Wines by the $\mathrm{pH}$ Differential Method: Collaborative Study. Journal of AOAC International, 88, 1269-1278.

https://doi.org/10.1093/jaoac/88.5.1269

[12] AFNOR (Association Française de Normalisation) (1991) Recueil des normes françaises des fruits et des produits fruitiers. Troisième Edition, Association Française de Normalisation, Paris, 411-422.

[13] De Man, J.C., Rogosa, M. and Sharpe, M.E. (1960) Medium for the Cultivation of Lactobacilli. Journal of Applied Bacteriology, 23, 130-135.

https://doi.org/10.1111/j.1365-2672.1960.tb00188.x

[14] Richard, G., Youkparigha, F.O., Aigberua, A.O., Izah, S.C. and Morayo, E.O. (2021) Microbial Density and Associated Physicochemical Properties of Palm Wine in Wilberforce Island, Nigeria. Research and Review Insights, 5, 1-5. https://doi.org/10.15761/RRI.1000163

[15] Karamoko, D., Théodore Deni, N., Aboya Moroh, J-L., Jean-Paul Bouatenin, K.M. and Dje, K.M. (2016) Biochemical and Microbial Properties of Palm Wine: Effect of Tapping Length and Varietal Differences. Food and Nutrition Sciences, 7, 763-771. https://doi.org/10.4236/fns.2016.79077

[16] Picariello, L., Gambuti, A., Petracca, F., Rinaldi, A. and Moio, L. (2017) Enological Tannins Affect Acetaldehyde Evolution, Colour Stability and Tannin Reactivity during Forced Oxidation of Red Wine. International Journal of Food Science and Technology, 53, 228-236. https://doi.org/10.1111/ijfs.13577

[17] Behrends, A. and Weber, F. (2017) Influence of Different Fermentation Strategies on the Phenolic Profile of Bilberry Wine (Vaccinium myrtillus L.). Journal of Agricultural and Food Chemistry, 65, 7483-7490.

https://doi.org/10.1021/acs.jafc.7b02268

[18] Oliveira, J., Azevedo, J., Silva, A.M., Teixeira, R.N., Cruz, L., Mateus, N. and De Freitas, V. (2010) Pyranoanthocyanin Dimers: A New Family of Turquoise Blue Anthocyanin-Derived Pigments Found in Port Wine. Journal of Agricultural and Food Chemistry, 58, 5154-5159. https://doi.org/10.1021/if9044414

[19] Gutiérrez-Escobar, R., Aliaño-González, M.J. and Cantos-Villar, E. (2021) Wine Polyphenol Content and Its Influence on Wine Quality and Properties: A Review. Molecules, 26, Article No. 718. https://doi.org/10.3390/molecules 26030718

[20] He, F., Liang, N.N., Mu, L., Pan, Q-H., Wang, J., Reeves, M.J. and Duan, C.-Q. (2012) Anthocyanins and Their Variation in Red Wines I. Monomeric Anthocya- 
nins and Their Color Expression. Molecules, 17, 1571-1601. https://doi.org/10.3390/molecules 17021571

[21] Zhang, Z., Li, J. and Fan, L. (2018) Evaluation of the Composition of Chinese Bayberry Wine and Its Effects on the Color Changes during Storage. Food Chemistry, 276, 451-457. https://doi.org/10.1016/j.foodchem.2018.10.054

[22] Xia, Q., Li, R., Zhao, S., Chen, W., Chen, H., Xin, B., Huang, Y. and Tang, M. (2011) Chemical Composition Changes of Postharvest Coconut Inflorescence Sap during Natural Fermentation. African Journal of Biotechnology, 10, 14999-15005.

[23] Santos, M.C., Nunes, C., Rocha, M.A.M., Rodrigues, A., Rocha, S.M., Saraiva, J.A and Coimbra, M.A. (2013) Impact of High-Pressure Treatments on the Physicochemical Properties of a Sulphur Dioxide-Free White Wine during Bottle Storage: Evidence for Maillard Reaction Acceleration. Innovative Food Science and Emerging Technologies, 20, 51-58. https://doi.org/10.1016/j.ifset.2013.07.001

[24] Oliveira, C.M., Ferreira, A.C.S., De Freitas, V. and Silva, A.M.S. (2011) Oxidation Mechanisms Occurring in Wines. Food Research International, 44, 1115-1126. https://doi.org/10.1016/j.foodres.2011.03.050

[25] Adou, M., Achille, T.F., Désiré, A.Y. and Georges, A.N.G. (2019) Stabilization and Sensory Evaluation of Cashew Apple Juice (Anacardium occidentale L.) from the Northeast Region in Côte d'Ivoire. Journal of Food Science and Nutrition Research, 2, 108-127.

[26] Mbaeyi-Nwaoha, I.E. and Okorie, B.I. (2016) Storage Studies of table Wine Produced from African Bush Mango (Irvingia gabonensis) and Watermelon (Citrullus lanatus) Blends. African Journal of Food Science and Technology, 7, 13-26. https://doi.org/10.14303/ajfst.2016.011

[27] Ogodo, A.C., Ugbogu, O.C., Agwaranze, D.I. and Ezeonu, N.G. (2018) Production and Evaluation of Fruit Wine from Mangifera indica (cv. Peter). Applied Microbiology, 4, Article No. 144.

[28] Obiekezie, O.P., Efiuvwevwere, B.J.O. and Eruteya, O.C. (2020) Production, Preservation and Shelf-Life Evaluation of Wine from Banana Fruit (Musa acuminata Colla). Journal of Advances in Microbiology, 20, 47-61. https://doi.org/10.9734/jamb/2020/v20i930280

[29] Bayoi, R.J., Vandi, Y., Foundikou, B.Y. and Etoa, F-X. (2021) Traditional Processing, Physicochemical Property, Phytochemical Content, and Microbiological and Sensory Quality of the Yellow “Téa Lémi” Wine Made in the Far-North of Cameroon. Journal of Food Quality, 2021, Article ID: 6634747, 12 p.

https://doi.org/10.1155/2021/6634747. 